\title{
Hemşirelik Öğrencilerinde Duygusal Zekâ ve Mesleki Değerlerin Karşılaştırmaası
}

\author{
Hande YAĞCAN ${ }^{1}$, (iD) Elif ULUDAĞ², (iD) Hülya OKUMUŞ3
}

${ }^{1}$ Dr. Öğr. Üyesi, Dokuz Eylül Üniversitesi Hemşirelik Fakültesi, Doğum ve Kadın Hastalıkları Hemşireliği AD., İzmir, Balçova

${ }^{2}$ Dr. Öğr. Üyesi, Pamukkale Üniversitesi, Sağlık Bilimleri Fakültesi, Hemşirelik Bölümü, Doğum- Kadın Sağlığı ve Hastalıkları Hemşireliği AD., Denizli, Kınıklı Kampüsü

${ }^{3}$ Prof. Dr., Dokuz Eylül Üniversitesi Hemşirelik Fakültesi, Doğum ve Kadın Hastalıkları Hemşireliği AD., Emekli öğretim Üyesi

\section{Öz}

Giriș: Giriș: Hemşirelerin, bakımı etkin biçimde verebilmesi için, mesleğin profesyonel değerlerini bilmesi ve içselleştirmesi gerekmektedir. Duygusal zekânın yüksek olmasının bireylerin iş, eğitim gibi alanlarda istedikleri sonuca ulaşabilmesinde etkili olduğu vurgulanmaktadır. Bu nedenle hemşirelik öğrencilerinin duygusal zekâlarının ve mesleki değerlerinin çalışılması önemlidir. Amaç: Bu araştırma; hemşirelik öğrencilerinin duygusal zekâları ile mesleki değerlerinin karşılaştırılması ve aralarındaki ilişkinin belirlenmesi amacıyla planlanmıştır. Yöntem: Araştırma 13-15 Nisan 2017 tarihleri arasında bir devlet üniversitesinin hemşirelik fakültesinde eğitim görmekte olan 505 lisans öğrencisi ile yapılmıştır. Veri toplama aracı olarak "Öğrenci Bilgi Formu”, "Duygusal Zekâ Özellik Ölçeği-Kısa Formu (DZÖÖ-KF)" ve "Revize Edilen Hemşirelerin Mesleki Değerleri Ölçeği (HMDÖ-R)" kullanılmıştır. Verilerinin analizinde Shapiro-Wilk, Mann Whitney U, Kruskal Wallis ve Spearman Korelasyon analizleri kullanılmıştır. Bulgular: Kız (107.88 \pm 15.34$)$ ve erkek $(103.81 \pm 16.83)$ öğrencilerin HMDÖ-R puan ortalamaları arasında anlamlı bir fark bulunmuştur $(\mathrm{p}=.040)$. Hemşirelerin Profesyonel Değerleri Ölçeğinin Bakım Verme faktöründe kız öğrencilerin puan ortalamaları $(59.57 \pm 8.75)$ erkeklerinkine $(57.06 \pm 9.93)$ göre anlamlı bir şekilde yüksek olup $(p=.030)$, Profesyonellik ve Güven faktörlerinde de kız öğrencilerin puan ortalamaları yüksek saptanmıştır. Kız öğrencilerde duygusallık alt boyutu puan ortalaması $(19.82 \pm 3.74)$ erkeklere $(18.88 \pm 3.66)$ göre daha yüksek bulunmuştur $(\mathrm{p}=.01, \mathrm{U}=16.586)$. Sosyallik ve öz kontrol alt boyutlarında erkeklerin, iyi oluş boyutunda kız öğrencilerin puan ortalamaları yüksek olup bu fark anlamlı bulunmamıştır. Kız (97.85 \pm 14.29$)$ ve erkek öğrencilerin (97.62 \pm 15.61) DZÖÖ-KF toplam duygusal zekâ alt boyutu puan ortalamaları arasında bir fark bulunmamıştır. Hemşirelik ögrencilerinin HMDÖ-R toplam puan ortalaması ve tüm alt boyutları ile DZÖÖ-KF toplam duygusal zekâ alt boyutu arasında $(\mathrm{p}=.000, \mathrm{r}=$ .31-.37) orta düzeyde pozitif yönde bir ilişki saptanmıştır. Sonuç: Hemşirelik öğrencilerinin cinsiyet farkı olmaksızın duygusal zekâ düzeyleri ile hemşirelik mesleği değerleri algılarının doğru orantılı arttığı görülmüştür. Hemşirelik öğrencilerinin cinsiyetlerine göre duygusal zekâ düzeyleri arasında anlamlı bir fark saptanmamıştır. Kız öğrencilerin erkeklere göre HMDÖ-R puanlarının daha yüksek olması mesleki değerlere uyum eğiliminin daha güçlü olduğu yönündedir.

Anahtar Sözcükler: Değerler, Duygusal Zekâ, Hemşirelik, Profesyonellik.

\section{Abstract}

The Comparison of Nursing Students' Emotional Intelligence and Professional Values

Background: Nurses need to know and internalize the professional values of the profession in order to provide care effectively. It is emphasized that high emotional intelligence is effective for individuals to achieve the desired result in areas such as work and education. Therefore, it is important to study the emotional intelligence and professional values of nursing students. Objectives: This study was planned to compare the emotional intelligence of nursing students with their professional values and to determine the relationship between them.

Methods: The study was applied to 505 students of a state nursing faculty between 13-15 April 2017. In data collection; "Information Questionnaire for Students”, “Trait Emotional Intelligence Scale- Short Form (TEIS-SF): Scale-Short Form and "Nurses Professional Values Scale-Revised (NPVS-R)” tools were used. Shapiro-Wilk, Mann Whitney U, Kruskal Wallis and Spearman Correlation were used in data analysis. Results: A statistically significant difference was determined among NPVS-R point averages of the female (107.88 \pm 15.34$)$ and male students $(103.81 \pm 16.83)(\mathrm{p}=.040, \mathrm{U}=17.178)$. In Giving Care factor of NPVS-R, point averages of the females $(59.57 \pm 8.75)$ were significantly higher compared to the males $(57.06 \pm 9.93)(\mathrm{p}=.030, \mathrm{U}=16.990)$, point averages of females were determined to be higher also in Professionalism and Confidence factors. No statistically significant difference was determined between TEIS-SF point averages of female $(97.85 \pm 14.29)$ and male $(97.61 \pm 15.61)$ students. Point averages of emotionality sub-dimension were determined to be significantly higher in females $(19.82 \pm 3.74)$ than males $(18.88 \pm 3.66)(\mathrm{p}=.010, \mathrm{U}=16.586)$. Point averages of males were determined to be higher in sociability and self-control sub-dimensions and point averages of females were determined to be higher in well-being sub-dimension; however, there was no statistically significant difference was determined. Furthermore, a low positive association was determined between NPVS-R total emotional intelligence subscale and TEIS-SF point averages and all subscales of nursing students $(\mathrm{p}=.000, \mathrm{r}=.31-.37)$. Conclusion: The emotional intelligence level of the nursing students and their perception for professional values is directly proportional, regardless of gender. No statistically significant difference was determined between emotional intelligence levels in accordance with their gender in nursing students. As NPVS-R points of female students were higher than males shows that their tendency to adapt to professional values is stronger than boys. Key Words: Emotional Intelligence, Nursing, Professionalism, Values.

Geliş Tarihi / Received: 07.08.2020 Kabul Tarihi / Accepted: 16.06.2021

Correspondence Author: Dr. Öğr. Üyesi, Dokuz Eylül Üniversitesi Hemşirelik Fakültesi, Doğum ve Kadın Hastalıkları Hemşireliği AD., İzmir, Balçova ORCID NO:0000-0001-9658-0449, E-mail: hande.yagcan@gmail.com

Cite This Article: Yağcan H, Uludağ E, Okumuş H. Hemşirelik Öğrencilerinde Duygusal Zekâ ve Mesleki Değerlerin Karşılaştırması Dokuz Eylül Üniversitesi Hemşirelik Fakültesi Elektronik Dergisi. 2021; 14(3): 224-231 
uygusal zekâ kavramı empati yapabilme, yeni ortam ve durumlara uyum sağlayabilme, problem çözebilme, mizacını

D kontrol edebilme ve bağımsız davranabilme becerileriyle birlikte değerlendirilmektedir. Bir bireyin duygusal zekâsının yüksekliği, bu bireyin iş, eğitim, özel yaşam gibi birçok alanında istediği sonuçlara ulaşabilmek için duygularını istediği şekilde kullanabildiğini göstermektedir (1-5).

Araştırmalara göre, duygusal zekâsı yüksek bireyler, değişime daha iyi uyum sağlama becerisine sahip olup, stresle daha iyi baş edebilmekte ve daha sosyal olmaktadır. Ayrıca duygusal zekânın analitik zekâya göre bireysel ve mesleki yaşamda başarının belirleyicisi olduğu kabul edilmektedir (1). Duygusal zekâsı yüksek olan bireyler, duygularını daha iyi ifade eder ve yönetirler (2). Yapılan bir çalışmada öğrencilerin algıladıkları öz yeterliliğin, sosyal becerilerine ve duygusal zekâlarına göre farklılık gösterdiği, birbirleri ile ilişkili oldukları ve cinsiyetlerinin öz yeterliliği, sosyal becerileri ve duygusal zekâyı etkilemediği saptanmıştır (3). Duygusal zekâ ölçeği kullanılarak yapılan hemşirelik çalışmalarında, duygusal zekânın stresle başetme, farkındalık, yönetim, iletişim, empati, uygulama, etik muhakeme becerilerini ve hasta memnuniyetini olumlu problem çözme becerilerini negatif yönde etkilediği saptanmıştır (4-8). Çankaya \& Eriş'in (2020) yaptıkları bir çalışmada ise medeni durum, mesleki deneyim ve yaş grupları gibi demografik özelliklerin hemşire ve ebelerin duygusal zekâ düzeylerinde anlamlı farklılıklara yol açtığı belirlenmiştir (9).

Hemşirelerin, bakımı en etkin biçimde verebilmesi için, ne yaptığını, niçin yaptığını anlaması, hemşirelik felsefesine ve profesyonel hemşireliğe uygun bilgi, beceri ve davranışları kazanması, mesleki davranışlarını yönlendirerek nitelikli hizmet vermesini sağlayan mesleki değerlerinin farkında olması önemlidir (10-12). Hemşirelik mesleğinin değerleri ise alturizm, eşitlik, insan onuru, adalet ve doğruluk olarak belirtilmektedir (7). Hemşirelik mesleğinde profesyonellerin kurallara, mevcut duruma ve bireysel özelliklere dikkatli yaklaşımı, bireylere hizmet verirken, davranış ve tutumlarını savunurken uygulamalarında yetkin olmaları, akılcı ve etik davranmaları ve mesleki değerlerini kullanmaları beklenmektedir $(7,12)$. Göriş ve ark.'nın (2014) "Hemşirelikte Profesyonel Değerler Ölçeğini” kullandıkları çalışmalarında 40 yaş ve üstü, erkek, bekâr olan, yüksek lisans yapan, idari görevi olan, dernek üyeliği bulunan, bilimsel toplantılara katılan ve profesyonel değerler konusunda eğitim alan hemşirelerin profesyonel değerler ölçeği puanları daha yüksek bulunmuştur (13).

Hemşirelerin cinsiyetlerine göre duygusal zekâlarının bu değerlerin fakında olmalarını etkileyip, etkilemediği bilinmemektedir. Ülkemizde yapılan hemşirelerin cinsiyetlerine göre duygusal zekâlarının belirlenmesi ile ilgili bir çalışmada kız öğrencilerin duygusal zekâ ölçeği puanları erkek öğrencilerden yüksek bulunmuştur. Öğrencilerin yaşı, girişkenliği ve sınıf düzeyi arttıkça duygusal zekâ puanlarının arttığı saptanmıştır (14). Hemşirelik değerleri ile duygusal zekânın karşılaştırıldığı başka bir çalışmada ise hemşirelerin eğitim durumları, mesleklerini severek yapma durumları, cinsiyetleri, çocuk sahibi olma durumları, çalıştıkları pozisyon ve çalışma yıllarının duygusal zekâ düzeyleri ile ilişkili olduğu belirtilmektedir. Ayrıca yapılan çalışmalarda hemşirelerin profesyonel değerleri ölçeği ve duygusal zekâ düzeyleri arasında pozitif yönlü anlamllık saptanmıştır $(15,16)$. Ancak öğrenci hemşirelerin cinsiyetlerine göre duygusal zekâlarının hemşirelik değerlerine olan etkisine ilişkin literatürde güncel bir çalışmaya rastlanmamıştır. $\mathrm{Bu}$ araştırmanın, hemşirelik mesleki değerlerinin cinsiyete göre içselleştirilmesine yönelik eğitim ve uygulamalara rehberlik edeceği ve daha etkin stratejilerin geliştirilmesi için yararlı bilgiler sağlayacağı öngörülmektedir.

Hemşireliğin profesyonel değerlerinin hastalarla, meslektaşlarla, diğer ekip üyeleri ile ve toplumla etkileşimlerde rehberlik eden uygulamalar olduğu ifade edilmektedir (17). Hemşirelik mesleğinin profesyonel değerlerinin yaş, cinsiyet, medeni durum ve eğitim durumu gibi sosyo-demografik faktörlerden etkilenebildiği görülmektedir (7). Hemşirelik mesleği gibi, duyguların önemli rol oynadığı mesleklerde, tüm etkileyen etmenlerin yanında hemşirelerin duygularının da mesleki değerleri etkilemede önemli olduğu düşülmektedir. Bu nedenle duygusal zekânın hemşireliğin mesleki değerleri ile ilişkisinin belirlenmesinin ve cinsiyetlerine göre duygusal zekâları ile mesleki değerlerinin karşılaştırılmasının önemli olduğu düşünülmektedir.

\section{Araştırma Soruları}

- Öğrenci hemşirelerin cinsiyetlerine göre duygusal zekâları arasında fark var mıdır?

- Öğrenci hemşirelerin cinsiyetlerine göre mesleki değer algıları arasında fark var mıdır?

- Öğrenci hemşirelerin duygusal zekâ düzeyleri ile mesleki değer algıları arasında ilişki var mıdır?

\section{Amaç}

$\mathrm{Bu}$ araştırma; hemşirelik öğrencilerinin cinsiyetlerine göre duygusal zekâları ile mesleki değerlerinin karşılaştırılması ve aralarındaki ilişkinin belirlenmesi amacıyla planlanmıştır

\section{Araştırmanın Tipi}

\section{Yöntem}

Analitik kesitsel tipte bir çalışmadır.

\section{Araştırmanın Yapıldı̆̆ Yer}

Araştırmanın verileri 13-15 Nisan 2017 tarihleri arasında İzmir ilinde bir devlet üniversitesi hemşirelik fakültesinde toplanmıştır.

\section{Araşturmanın Evreni/Örneklemi}

Araştırma evrenini çalışmanın yürütüldüğü hemşirelik fakültesinde öğrenim görmekte olan tüm üçüncü sınıf ve intörn öğrencileri (N=600 öğrenci) oluşturmuştur. Araştırmada örneklem seçimine gidilmemiş olup çalışma 505 gönüllü öğrenci ile tamamlanmıştır. Araştırmada sınıflar arası karşılaştırma hedeflenmediği için, araştırma evrenine hemşirelik mesleki değerlerinin gelişmişlik düzeylerinde homojenliğin sağlanılması amacıyla üçüncü sınıf ve intörn öğrencileri dahil edilmiştir. 


\section{Veri Toplama Araçlart-Geçerlik ve Güvenirlik Bilgileri}

Araştırmada veri toplama aracı olarak "Öğrenci Bilgi Formu", "Duygusal Zekâ Ölçeği-Kısa Formu" ve "Hemşirelerin Profesyonel Değerleri Ölçeği” kullanılmıştır.

Öğrenci Bilgi Formu:

Araştırmada öğrencilerin sosyo-demografik özelliklerini saptamak için araştırmacılar tarafindan literatür doğrultusunda oluşturulan formda; yaş, cinsiyet, hemşirelik mesleğini seçme nedeni, meslek seçimini etkileyen kişi ve öğrencilik sürecinde mesleği sevme durumu içeren sorular yer almaktadır (1-17).

Duygusal Zekâ Özellik Ölçeği-Kısa Formu (DZÖÖ-KF):

Petrides ve Furnham'ın $(2,18)$ tarafindan bireyin duygusal yeterlikleriyle ilgili kendini algılama düzeyini belirlemek üzere geliştirilmiş bir ölçektir. Trait Emotional Intelligence Scale (TEIQue) formunun uzun formatına dayanmaktadır (1). Ölçek orijinalinde 30 maddeden oluşan bir ölçme aracıdır. Deniz ve arkadaşları (2013) tarafından Türkçe geçerlik güvenirliği yapılan ölçek 20 maddeye indirilmiştir. Ölçekte duygusal zekânın beş boyutuna (iyi oluş, öz kontrol, duygusallık, sosyallik ve toplam duygusal zekâ) ilişkin toplam 20 madde bulunmaktadır. Ölçekte, "kesinlikle katılmıyorum" dan "kesinlikle katılıyorum" a kadar 7'li likert tipi puanlama yapılmaktadır. Ölçek alt boyutları "Öznel iyi oluş" $(6,13,16,18$ maddeleri), "Öz kontrol” (2*, 4*, 10, $14^{*}$ maddeleri), "Duygusallık" (5*,11*,15, 19* maddeleri), "Sosyallik" $(3,7 *, 8,17 *$ maddeleri) ve "Toplam duygusal zekâ" $\left(1,9^{*}, 12^{*}, 20\right)$ oluşmaktadır $(19) .\left(^{*}\right)$ İşaretli olan maddeler ters çevrilerek puanlanmaktadır. Ölçek toplam puanı hesaplanmadığı için alınabilecek maksimum ve minimum puanlar ölçeğin geliştirildiği çalışmada ve Türkçe geçerlik güvenirlik çalışmasında belirtilmemiştir $(2,18,19)$. Yapılan farklı çalışmalarda cronbach alfa katsayıları iyi oluş için .74-.80, öz kontrol için .59-.75, duygusallık için .66-.69, sosyallik için .60-.69 ve toplam duygusal zekâ için .87-.90 arasında değişmektedir $(20,21)$. Deniz ve arkadaşları (2013) tarafından DZÖÖ̈-KF'nun alt boyutlarının cronbach alfa katsayıları; İyi Oluş faktörü için .72, Öz kontrol için .70 , Duygusallık için .66, Sosyallik için .70 ve Toplam Duygusal Zekâ .81 olarak bulunmuştur (19). Puanların yüksekliği duygusal zekâ özelliğinin yüksekliği anlamına gelmektedir. Çalışmada DZÖÖ-KF ölçeği alt boyutları cronbach alfa katsayıları; İyi Oluş faktörü için .69, Öz kontrol için .73, Duygusallık için .62 ve Sosyallik için .71 ve Toplam Duygusal Zekâ için .98 olarak bulunmuştur.

Revize Edilen Hemşirelerin Mesleki Değerleri Ölçeği (HMDÖ-R): (Nurses Professional Values Scale- NPVS-R):

Hemşirelerin ve hemşirelik öğrencilerinin mesleki değerleri algıllama düzeyini belirlemek üzere Weis ve Schank (2009) tarafindan geliştirilen ve Türkçe geçerlik güvenirliği Acaroğlu (2014) tarafından yapılmış olan, beşli likert tipte (1-önemli değil, 2-biraz önemli, 3-önemli, 4-çok önemli, 5-çok fazla önemli), 26 madde içeren bir ölçektir $(10,22)$. Ölçeğin toplam puanı, yanıtlara karşılık gelen sayısal değerlerin toplanması ile elde edilir. Ölçekte ters çevrilerek puanlanan madde bulunmamaktadır. Ölçekten alınabilecek toplam puanlar 26-130 arasındadır. Yüksek puan mesleki değerlere uyumun güçlü olduğunu gösterir. Weis ve Schank (2009), original ölçeğin psikometrik özelliklerini test ettikleri çalışmada Cronbach alfa katsayısını .92 bulmuştur. Aynı çalışmada, ölçeğin, faktör yük değeri .46-.79 aralığında değişen beş faktör ile desteklendiği saptanmış ve bunlar Bakım, Aktivizm, Güven, Profesyonellik ve Adalet olarak isimlendirilmiştir (22). Ölçeğin çok faktörlü yapısı özgün çalışmada beş faktörden oluşurken, Acaroğlu'nun geçerlik güvenirlik çalışmasında ise üç faktörde toplanmıştır. Bu faktörler "Bakım" (12-25 maddeleri arası), "Profesyonellik" (4- 9, 11, 26 maddeleri) ve "Güven” (1-3 maddeleri arası) olarak belirlenmiştir. Cronbach alfa katsayısı .96 , madde toplam puan korelasyonları .47 ile .79 arasında bulunmuştur (10). Çalışmada ölçeğin cronbach alfa katsayısı .94 , madde toplam puan korelasyonları .38 ile .80 arasında, alt boyutların cronbach alfa katsayıları; Bakım faktörü için .93 , Profesyonellik faktörü için .87 ve Güven faktörü için .73 arasında bulunmuştur.

\section{Verilerin Toplanmast}

Araştırma verileri kurum ve ilgili sınıfların ders eğitmeninin izinleri alınarak eğitmenin ve öğrencilerin ortak uygun zaman diliminde, genellikle ders başlangıcından önce araştırmacılar tarafından toplanmıştır. İlgili formlar, araştırma ile ilgili ön açıklama yapılıp yazılı onamları alındıktan sonra öğrencilere tarafından doldurulmuştur. Formların öğrenciler tarafindan doldurulması $10 \mathrm{dk}$. sürmüş̧ür.

\section{Verilerin Değerlendirilmesi}

Sosyo demografik verilerin sayı, yüzde, sıklık analizleri yapılmıştır. Değişkenler arasında karşılaştırma yapmadan önce ShapiroWilk normallik analizi yapılmış ve verilerin normal dağılmadığı saptanmıştır $(p<0.05)$. Hemşirelik öğrencilerinin duygusal zekâlarının hemşirelik mesleğinin profesyonel değerleri üzerine etkisini belirlemek amacıyla parametrik testlerden iki ortalama arasındaki farkın önemlilik testi ve korelasyon analizi yapılmıștır. Hemşirelik öğrencilerinin cinsiyetlerine göre duygusal zekâları ve hemşirelik mesleğinin profesyonel değerleri algıları normal dağılım sağlanmadığı için değerlendirmede nonparametrik Mann Whitney U ve Kruskal Wallis testleri kullanılmıştır. Duygusal Zekâ Özellik Ölçeği ve Revize Edilen Hemşirelerin Mesleki Değerleri Ölçeği'nin cronbach alfa katsayıları hesaplanmıştır. Çalışma verilerinin analizinde Shapiro-Wilk, Mann Whitney U, Kruskal Wallis ve Spearman Korelasyon analizi kullanılmıştır.

Çalışmanın Bağımlı Değişkeni: Hemşirelik mesleği değerleri algısı

Çalışmanın Bağımsız Değişkeni: Öğrencilerin cinsiyetlerine göre duygusal zekâ puanları

\section{Araștırmanın Etik Yönü}

Araştırmanın uygulanabilmesi için, ilgili üniversitenin Hemşirelik Fakültesi Dekanlığından kurum izni (Tarih/Sayı: 21.03.2017/19396244-108.99) ve ilgili üniversitenin girişimsel olmayan araştırmalar etik kurulundan (Tarih/Sayı:13.04.2017/2017/08-17) etik kurul izni alınmıştır. Araştırma öncesinde ölçek kullanım izinleri alınmış olup hemşirelik öğrencilerine çalışmanın amacı açıklanarak, gönüllü hemşirelik öğrencilerinden sözel onam ve aydınlatılmış onam formu ile yazılı izinleri alınmıştır. Makalede araştırma ve yayın etiğine uyulmuştur. 


\section{Bulgular}

Çalışmaya 408 kız (\%80.8) ve 97 (\%19.2) erkek öğrenci katılmış olup veriler cinsiyete göre normal dağılım göstermemektedir $(\mathrm{p}=.000)$. Öğrencilerin yaş ortalaması $22.20 \pm 1.38$ olup, \%69.1'i mesleği isteyerek seçmiştir. Meslek seçimlerini öğrencilerin \%45.3'ü kendi kararıyla, \%41'i ailesinin isteğiyle, \%9.3'ü öğretmeninin ve \%4.4'ü arkadaşlarının yönlendirmesi ile yapmıştır. Öğrencilerin \%84.8'i hemşirelik mesleğini sevdiğini ve \%76's1 güçlü bulduğunu belirtmiştir.

\section{Duygusal Zekâ:}

Duygusal zekâ ölçeği alt boyutları puan ortalamaları; İyi Oluş $19.96 \pm 3.76$, Öz Kontrol 18.41 \pm 4.06 , Duygusallık 19.63 \pm 3.74 , Sosyallik $19.92 \pm 4.07$ ve Toplam Duygusal Zekâ alt boyutu puan ortalaması $97.80 \pm 14.53$ olarak saptanmıştır.

\section{Mesleki Dĕgerler:}

Öğrencilerin HMDÖ-R toplam puan ortalaması 107.09 $\pm 15.70(\min =61-\max =130)$ olup ortalamanın üzerindedir. Destekleyen 3 faktör puan ortalamaları; Bakım Verme 59.08 $\pm 9.02(\min =34-\max =70)$; Profesyonellik $31.96 \pm 5.30(\min =17-\max =$ 40) ve Güven $11.92 \pm 2.00(\min =3-\max =15)$ olarak yüksek bulunmuştur.

K1z öğrencilerin HMDÖ-R'nün genel puan ortalamaları (107.87 \pm 15.33$)$ ve erkek öğrencilerin puan ortalamalarından (103.81 \pm 16.83$)$ daha yüksek olup, öğrencilerin HMDÖ-R'nün genel puan ortalamaları arasında istatistiksel olarak anlamlı bir fark bulunmuştur $(\mathrm{U}=17.178, \mathrm{p}=.040)$. Hemşirelerin profesyonel değerleri ölçeğinin Bakım Verme faktöründe kız öğrencilerin puan ortalamaları $(59.57 \pm 8.75)$ erkek öğrencilerinkine $(57.06 \pm 9.93)$ göre daha yüksek olup bu fark istatistiksel olarak anlamlıdır $(\mathrm{U}=16.990, \mathrm{p}=.030)$. Profesyonellik ve Güven faktörlerinde de kız öğrencilerin puan ortalamaları erkek öğrencilerin puan ortalamalarından daha yüksek saptanmış olmasına rağmen bu sonuçlar istatistiksel düzeyde anlamlı bulunmamıştır ( $\mathrm{p}>.050$ ) (Tablo 1).

Tablo 1. Hemşirelik Öğrencilerinin Cinsiyetlerine Göre DZÖÖ-KF ve HMDÖ-R Puanları Arasındaki Fark

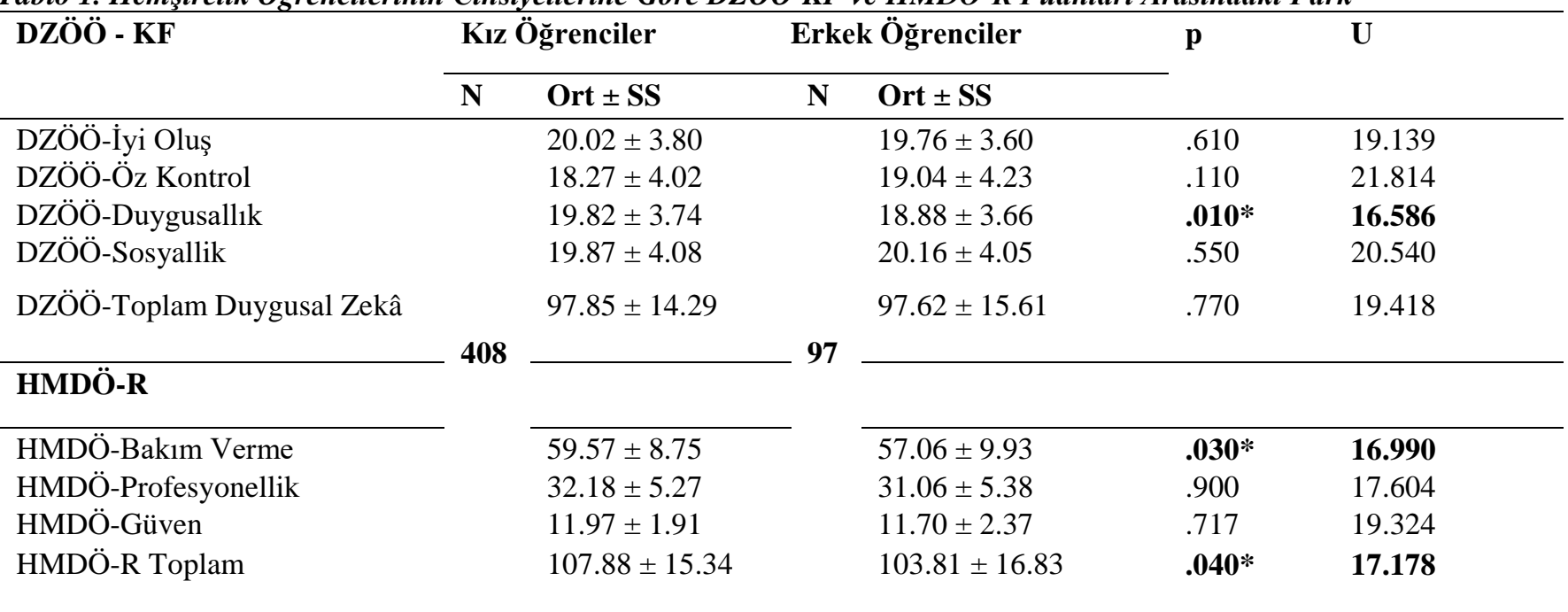

$* p \leq .050$

K1z $(97.85 \pm 14.29)$ ve erkek öğrencilerin $(97.62 \pm 15.61)$ toplam duygusal zekâ alt boyutu puan ortalamaları arasında istatistiksel düzeyde anlamlı bir fark bulunmamıştır. Kız öğrencilerde duygusallık alt boyutu puan ortalaması (19.82 \pm 3.74 ) erkek öğrencilere göre $(18.88 \pm 3.66)$ daha yüksek bulunmuş olup bu fark istatistiksel olarak anlamlıdır $(\mathrm{U}=16.586, \mathrm{p}=.010)$. Sosyallik ve öz kontrol alt boyutlarında erkeklerin, iyi oluş boyutunda kız öğrencilerin puan ortalamaları yüksek bulunurken bu fark istatistiksel olarak anlamlı bulunmamıştır ( $\mathrm{p}>.050)$ (Tablo 1).

Kı̈ öğrencilerin \%69.6'sı ve erkek öğrencilerin \%67'si mesleğini isteyerek seçmiş olup bu fark istatistiksel olarak anlamlı bulunmamıştır $\left(\mathrm{X}^{2}=0.248, \mathrm{p}=0.619\right)$. Öğrencilerin hemşirelik mesleğini isteyerek seçenlerin DZÖÖ-KF alt boyutları; İyi Oluş $(U=22.286, p=.000)$, Duygusallık $(U=22.760, p=.000)$ ve Toplam Duygusal Zekâ $(U=22.787, p=.000)$ puan ortalamaları istatistiksel olarak anlamlı düzeyde yüksek saptanmıştır. Kız öğrencilerin mesleğini isteyerek seçenlerin DZÖÖ-KF İyi oluş $(\mathrm{U}=13.835, \mathrm{p}=.010)$, alt boyut puan ortalamaları istatistiksel olarak anlamlı düzeyde yüksek saptanmıştır. Erkek öğrencilerin mesleğini isteyerek seçenlerin DZÖÖ-KF Duygusallık $(U=622.500, p=.001)$, Sosyallik $(U=750.000, p=.026)$, Öz kontrol $(U=601.000, p=.001)$ ve Toplam Duygusal Zekâ $(U=700.500, p=.009)$ alt boyutları puan ortalamaları istatistiksel olarak anlamlı düzeyde yüksek saptanmıştır. Öğrencilerin hemşirelik mesleğini isteyerek seçmeleri ve HMDÖ-R ölçeği alt boyutları ve toplam puan ortalamaları arasında istatistiksel olarak anlamlı bir fark saptanmamıştır $(\mathrm{p}>0.005)$. 
Tablo 2. Öğrencilerin HMDÖ-R ve DZÖÖ-KF Puan Ortalamaları Arasındaki İlişsi DZÖÖ-KF

\begin{tabular}{lllllll}
\hline HMDÖ-R & & İyi Oluș & Öz Kontrol & Duygusalık & Sosyallik & $\begin{array}{l}\text { Toplam Duygusal } \\
\text { Zekâ }\end{array}$ \\
\hline Bakım Verme & $\mathbf{r}$ & $\mathbf{. 3 2}$ & .17 & .25 & .27 &. $\mathbf{3 6}$ \\
& $\mathbf{p}$ & .000 & .000 & .000 & .000 & .000 \\
\hline Profesyonellik & $\mathbf{r}$ & .28 & .16 & .21 & .25 & .31 \\
& $\mathbf{p}$ & .000 & .000 & .000 & .000 & .000 \\
\hline Güven & $\mathbf{r}$ & .28 & .17 & .23 & .26 & .33 \\
& $\mathbf{p}$ & .000 & .000 & .000 & .000 & .000 \\
\hline Toplam & $\mathbf{r}$ & $\mathbf{. 3 3}$ & .18 & .25 & .28 & .37 \\
& $\mathbf{p}$ & .000 & .000 & .000 & .000 & .000 \\
\hline
\end{tabular}

Hemşirelik öğrencilerinin HMDÖ-R toplam puan ortalaması ve tüm alt boyutları ile DZÖÖ-KF toplam duygusal zekâ alt boyutu arasında $(\mathrm{p}=.000, \mathrm{r}=.31-37)$ orta düzeyde pozitif yönde istatistiksel olarak anlamlı bir iliş̧i saptanmıştır (Tablo 2).

Kız öğrencilerin HMDÖ-R toplam puan ortalamaları ile DZÖÖ Toplam Duygusal Zekâ $(p=.000, r=.314)$ alt boyutu arasında orta düzeyde ve İyi Oluş ( $\mathrm{p}=.000, \mathrm{r}=.287)$, Duygusallık $(\mathrm{p}=.000, \mathrm{r}=.216)$, Sosyallik $(\mathrm{p}=.000, \mathrm{r}=.221)$, Öz Kontrol alt boyutu arasında $(\mathrm{p}=.003, \mathrm{r}=.148)$ düşük düzeyde pozitif yönde istatistiksel olarak anlamlı bir ilişki saptanmıştır. HMDÖR Bakım alt boyutu ile DZÖÖ Toplam Duygusal Zekâ $(p=.000, r=.321)$ alt boyutu arasında orta düzeyde ve İyi Oluş $(\mathrm{p}=$ $.000, r=.293)$, Duygusallık $(p=.000, r=.210)$, Sosyallik $(p=.000, r=.236)$, Öz Kontrol alt boyutları arasında $(p=.001, r=$ .158) düşük düzeyde pozitif yönde istatistiksel olarak anlamlı bir ilişki saptanmıştır. HMDÖ-R Profesyonellik alt boyutu ile DZÖÖ Toplam Duygusal Zekâ ( $\mathrm{p}=.000, \mathrm{r}=.272)$, İyi Oluş $(\mathrm{p}=.000, \mathrm{r}=.256)$, Sosyallik $(\mathrm{p}=.000, \mathrm{r}=.221)$, Duygusallık $(\mathrm{p}$ $=.002, \mathrm{r}=.156)$ ve Öz Kontrol alt boyutları arasında $(\mathrm{p}=.001, \mathrm{r}=.141)$ düşük düzeyde pozitif yönde istatistiksel olarak anlamlı bir ilişki saptanmıştır. HMDÖ-R Güven alt boyutu ile DZÖÖ Toplam Duygusal Zekâ $(p=.000, r=.287)$, İyi Oluş (p $=.000, r$ $=.258)$, Sosyallik $(\mathrm{p}=.000, \mathrm{r}=.206)$, Duygusallık $(\mathrm{p}=.000, \mathrm{r}=.212)$ ve Öz Kontrol $(\mathrm{p}=.005, \mathrm{r}=.139)$ alt boyutları arasinda düşük düzeyde pozitif yönde istatistiksel olarak anlamlı bir iliş̧ki saptanmıştır.

Erkek öğrencilerin HMDÖ-R toplam puan ortalamaları ile DZÖÖ Toplam Duygusal Zekâ $(\mathrm{p}=.000, \mathrm{r}=.570)$, Sosyallik $(\mathrm{p}=.000, \mathrm{r}=.512)$ alt boyutları arasında yüksek düzeyde, İyi Oluş $(\mathrm{p}=.000, \mathrm{r}=.481)$, Duygusallık $(\mathrm{p}=.000, \mathrm{r}=.413)$, Öz Kontrol $(\mathrm{p}=.001, \mathrm{r}=.345)$ alt boyutu arasında alt boyutları arasında orta düzeyde, pozitif yönde istatistiksel olarak anlamlı bir ilişki saptanmıştır. HMDÖ-R Bakım alt boyutu puan ortalaması ile DZÖÖ Toplam Duygusal Zekâ $(\mathrm{p}=.000, \mathrm{r}=.538)$, Sosyallik $(\mathrm{p}=.000, \mathrm{r}=.503)$ alt boyutları arasında yüksek düzeyde ve İyi Oluş $(\mathrm{p}=.000, \mathrm{r}=.461)$, Duygusallık $(\mathrm{p}=.000, \mathrm{r}=.376)$, Öz Kontrol alt boyutları arasında $(\mathrm{p}=.001, \mathrm{r}=.319)$ orta düzeyde, pozitif yönde istatistiksel olarak anlamlı bir ilişki saptanmıştır. HMDÖ-R Profesyonellik alt boyutu puan ortalaması ile DZÖÖ Toplam Duygusal Zekâ $(\mathrm{p}=.000, \mathrm{r}=.502)$ alt boyutu arasında yüksek düzeyde, İyi Oluş $(\mathrm{p}=.000, \mathrm{r}=.408)$, Duygusallık $(\mathrm{p}=.000, \mathrm{r}=.420)$, Sosyallik $(\mathrm{p}=.000, \mathrm{r}=.398)$ alt boyutları arasında orta düzeyde ve Öz Kontrol alt boyutu arasında $(\mathrm{p}=.004, \mathrm{r}=.288)$ düşük düzeyde pozitif yönde istatistiksel olarak anlamlı bir ilişki saptanmıştır. HMDÖ-R Güven alt boyutu puan ortalaması ile DZÖÖ Toplam Duygusal Zekâ ( $\mathrm{p}=.000, \mathrm{r}=.475)$, İyi Oluş $(\mathrm{p}=.000, \mathrm{r}=.400)$, Sosyallik $(\mathrm{p}=.000, \mathrm{r}=.466)$, Duygusallık $(\mathrm{p}=.002, \mathrm{r}=.313)$ ve Öz Kontrol $(\mathrm{p}=.002, \mathrm{r}=.318)$ alt boyutları arasında orta düzeyde pozitif yönde istatistiksel olarak anlamlı bir ilişki saptanmıştır.

\section{Tartışma}

Çalışmada hemşirelik öğrencilerinin DZÖÖ-KF toplam duygusal zekâ alt boyutu puan ortalaması $97.80 \pm 14.53$ olarak saptanmıştır. Talmana ve arkadaşlarının (2020) çalışmasında hemşirelik öğrencilerinin emosyonel zekâsının orta düzeyde olduğu ve ders başarı durumlarını etkilediği saptanmışır (23). Çalışmada ayrıca kız ve erkek öğrencilerin toplam duygusal zekâları arasında anlamlı bir fark bulunmamıştır. Benzer şekilde yapılan çalışmalarda duygusal zekâ açısından kadın ve erkek öğrenciler arasında istatistiksel olarak anlamlı bir fark olmadığı belirtilmektedir (3,24). Yapılan başka bir çalışmada ise kız öğrencilerin duygusal zekâ ölçeği puanları erkek öğrencilerden yüksek bulunmuştur (14). Ayrıca, çalışmada hemşirelik öğrencilerinin, HMDÖ-R puan ortalaması $107.09 \pm 15.70$ olup, kız öğrencilerin hemşirelik değerleri puan ortalamasının erkek öğrencilerden istatistiksel olarak anlamlı düzeyde yüksek olduğu saptanmıştır. Kız öğrencilerin hemşirelik değerleri ölçeği toplam ve bakım verme alt boyutu puan ortalamasının erkek öğrencilerden istatistiksel olarak anlamlı düzeyde yüksek olduğu, profesyonellik ve güven alt boyutlarının puan ortalamalarının da erkek öğrencilerden yüksek olduğu görülmektedir. Benzer şekilde Karadağlı'nın (2016) çalışmasında da kız öğrencilerin profesyonel değerleri puan ortalaması erkek öğrencilerden istatistiksel olarak anlamlı bir şekilde daha yüksek bulunmuştur (25). Göriş ve arkadaşlarının (2014) çalışmalarında ise erkek hemşirelerin profesyonel değerler ölçeği puanları daha yüksek olarak saptanmıştır. Mesleki kıdemin, uzmanlık alanının, pozisyonun, bekâr olmanın, yüksek lisans yapmanın, dernek üyeliğinin, bilimsel toplantılara katılmanın ve profesyonel değerler konusunda eğitim almanın hemşirelerin profesyonel değerlerini etkilediği belirtilmiştir (13). Kız öğrencilerde hemşireliğin mesleki değerlerinin toplumsal roller, normlar, dini inanışlar vb. gibi diğer faktörlerden erkek öğrencilere göre daha fazla etkilenmiş olabileceği düşünülebilir.

Duygusal zekâ ölçeğinin alt boyutlarından iyi oluşluk alt boyutu puan ortalamasının kız öğrencilerde, erkek öğrencilere göre daha yüksek olduğu görülmektedir. Duygusal zekânın duyguları anlama ve kişisel gelişimi sağlamak için duyguları düzenleme yeteneği olduğu belirtilmektedir. İyi oluşluk alt boyutu kişinin kendini değerlendirmesiyle ilgili maddeleri içermektedir. Duygusal zekânın, kişilerin sadece başkalarıyla değil kendisi ile de ne kadar iyi ilişki kurduğunu belirleyen bir yetenek olduğu belirtilmektedir. Ayrıca etkili liderlik davranışıyla da ilişkilendirilmiştir (26). Duygusal zekâ seviyesi yüksek hemşirelerin yoğun iş temposunda kendi ruh sağlıklarını koruyabildikleri ve hastalarına etkin ve kaliteli bakım verebildikleri 
belirtilmektedir (27). Bu nedenle, iyi oluşluk alt boyutunun hemşireliğin mesleki değerlerini etkilediği düşünülmekte olup çalışma da ilgili alt boyutun hemşirelik mesleki değerleri üzerine orta düzeyde anlamlı bir etkisi olduğu saptanmıştır.

Duygusal zekâ ölçeğinin alt boyutlarından öz kontrol alt boyutunun erkek öğrencilerde, kız öğrencilere göre daha yüksek olduğu görülmektedir. Duygusal zekâ ölçeği kullanılarak yapılan hemşirelik çalışmalarında, duygusal zekânın stresle baş etme, iletişim ve etik muhakeme becerilerini olumlu yönde etkilediği saptanmıştır (4-8). Duygusal zekânın hastalarla yaşanan olumsuzlukları olumlu duyguya dönüştürme becerisini ve kişisel güçlenmeyi artırdığı düşünülmektedir. Ayrıca duygusal zekânın bireyin kendi duygularını ve ilişkilerini yönetme yeteneğinin gelişmesine katkı sağladığı ifade edilmektedir (7). Hemşirelik mesleği değerlerinde ise insanların durumlar karşısında tutumlarının önemli yeri olduğu belirtilmektedir (28). Bu nedenle öz kontrolün hemşireliğin mesleki değerlerini etkilediği düşünülmekte olup çalışma da ilgili alt boyutun hemşirelik mesleki değerleri üzerine düşük düzeyde anlamlı bir etkisi olduğu saptanmıştır.

Duygusal zekâ ölçeğinin alt boyutlarından duygusallık alt boyutunun kız öğrencilerde, erkek öğrencilere göre istatistiksel olarak anlamlı bir şekilde daha yüksek olduğu görülmektedir. Hemşirelik mesleğinde başkalarının duygularının farkında olmanın hasta bakımındaki önemi bilinmektedir. Duygusal zekânın bireylerin duygularını anlamasına, yönetmesine ve işlerini kontrol altına almasına yardımcı olduğu belirtilmektedir (7,29). Duygusal zekânın mesleki doyum alma, stres seviyesi, tükenmişlik düzeyi üzerindeki etkileri konusunda fikir birliği bulunmaktadır. Duygusal zekâ, hasta bakım kalitesini ve sonuçlarını, karar vermeyi, eleştirel düşünmeyi, hemşirelerin iyilik durumunu ve hemşirelik uygulamalarını geliştirebilmek için önemli bir kavram olarak görülmektedir (29). Hemşireliğin profesyonel değerlerinde ise hastalarla, meslektaşlarla, diğer ekip üyeleri ve toplumla etkileşimin önemli olduğu belirtilmektedir (17). Ayrıca hemşirelik mesleğinin en önemli değerlerinden biri insan onurunun korunmasıdır (7). İnsanlarla doğru etkileşim kurmanın ve onurlarını korumanın, onların duygularını doğru anlamakla ilişkili olduğu bilinmektedir. Çalışmada hemşireliğin mesleki değerleri ile duygusallık alt boyutunu arasında zayıf düzeyde pozitif yönde bir ilişki saptanmış olsa da bu ilişkinin farklı bir araştırma potansiyeli taşıdığı düşünülebilir.

Duygusal zekâ ölçeğinin alt boyutlarından sosyallik alt boyutunun erkek öğrencilerde, kız öğrencilere göre daha yüksek olduğu görülmektedir. Sosyallik alt boyutunun kendini ifade edebilme becerilerini sorgulayan maddelerden oluştuğu görülmektedir. Duygusal zekâsı yüksek olan bireylerde kişiler arası etkileşim ve kendini ifade edebilme yeteneğinin yüksek olduğu belirtilmektedir. Duygusal zekâsı yüksek olan hemşirelerin sosyal becerilerinin ve bunun sonucunda problem çözme becerisinin de yüksek olmasının bakımın kalitesine yansıdığı ifade edilmektedir (13, 24, 29-31). Ancak hemşirelik öğrencileri ile yapılan bir çalışmada duygusal zekâ ile problem çözme becerileri arasında negatif yönde bir ilişki saptanmasına rağmen aynı zamanda sosyal olarak daha aktif olan öğrencilerin duygusal zekâlarının daha yüksek olduğu sonuçlarına ulaşılmıştır (5). Çalışmada sosyallik alt boyutu ile hemşirelerin mesleki değerleri alt boyutları arasında da düşük düzeyde pozitif yönde bir ilişki bulunmuştur. Bu nedenle sosyal olarak daha aktif olan öğrencilerin hemşireliğin mesleki değerlerinin olumlu etkileneceği düşünülmektedir. Sosyallik becerinin yalnızca duygusal zekâ düzeyini değil meslekten doyum alma düzeyini de artıracağı ön görülmektedir (8).

Çalışma da meslekten doyum almayı önemli düzeyde etkileyen faktörlerden biri olan mesleği kendi isteği ile ve severek seçmenin duygusal zekâ puanları üzerine istatistiksel olarak anlamlı bir şekilde olumlu etkisi olduğu görülmüştür. Literatürde hemşirelik değerleri ile duygusal zekânın karşılaştırıldığı bir çalışmada hemşirelerin mesleklerini severek yapma durumlarının hemşirelik değerleri ve duygusal zekâ düzeyleri ile ilişkili olduğu belirlenmiştir (15). Ancak çalışmamızda öğrencilerin hemşirelik mesleğini isteyerek seçmeleri ve HMDÖ-R ölçeği alt boyutları ve toplam puan ortalamaları arasında istatistiksel olarak anlamlı bir fark saptanmamıştır.

Öğrencilerin toplam duygusal zekâ alt boyutu puanlarının hemşirelik değerleri ile pozitif yönde orta düzeyde ilişkili olduğu saptanmıştır. Orak Niksarlı'nın (2017) hastanede çalışan hemşireler ile yaptığı araştırmada da aynı sonuca ulaşılmıştır (15). Ayrıca çalışmamızda erkek öğrencilerin hemşirelik değerleri ölçeği toplam ve alt boyutlarının, duygusal zekâ ölçeği toplam duygusal zekâ alt boyutu ile yüksek diğer alt boyutları arasında orta düzeyde pozitif yönde anlamlı ilişkide olduğu bulunmuştur. İlginç bir şekilde, kız öğrencilerin hemşirelik değerleri ölçeği toplam ve alt boyut puanlarının, duygusal zekâ ölçeği toplam duygusal zekâ alt boyutu ile orta düzeyde, diğer alt boyutları ile düşük düzeyde pozitif yönde anlamlı ilişkide olduğu ortaya çıkmıştır. Bu bulgular erkek hemşirelik öğrencilerinin hemşirelik değerlerinin duygusal zekâlarından kız öğrencilere göre daha yüksek düzeyde etkilendiğini göstermektedir. Göriş ve arkadaşlarının çalışmasında duygusal zekâ karşılaştırması yapılmasa da (2016) erkeklerin ve profesyonel değerler konusunda eğitim alanların profesyonel değerler ölçeği puanları daha yüksek olduğu saptanmıştır. Öğrencilerin aldıkları eğitimin duygusal zekalarını ve dolayısıyla hemşirelik değerleri algılarını etkilediği düşünülmektedir. Orak Niksarlı'nın (2017) araştırmasında hemşirelerin duygusal zekâları arttıkça mesleki değerlerinin de güçlendiği sonucuna varılmıştır (17). Tüm bu bulgular sonucunda, öğrencilerin duygusal zekalarının aldıkları eğitim ile gelişmesi sağlanabilirse hemşirelik değerleri ölçeğinin alt boyutları olan bakım verme, profesyonellik ve güven alt boyut becerilerinin de gelişeceği varsayımında bulunulabilmektedir. Bu sayede hemşirelik öğrencileri kendine güvenen ve güvenilen, otonomisi olan ve empati yapabilme becerilerine sahip, insanı bir bütün olarak görebilen profesyoneller olarak mezun olacaklardır.

Hemşirelik mesleği gibi, duyguların önemli rol oynadığı mesleklerde, sadece teknik deneyim değil, psikoloji odaklı bakım, kendisinin ve bakım verdiği grubun duygularının farkında olunmasının yani empati yapmasının mesleğin gelişmesinde ve ilerlemesinde önemli rol oynayacağı belirtilmektedir (7). Bu nedenle duygusal zekâ, klinik karar verme, eleştirel düşünme, pratikte bilgi kullanımı ile hemşirelerin verdikleri bakımın kalitesini etkileyebilecek önemli bir özellik olarak kabul edilmektedir. Ayrıca duygusal zekânın yüksek olması ile iş performansı ve hasta memnuniyeti arasında pozitif yönde ilişki olduğu belirtilmektedir (29). Uluslararası Hemşireler Konseyi (ICN) hemşirelik mesleğinin en önemli değerinin sağlıkl1/hasta bireyin esenliği olduğunu vurgulayarak, temel değerin yararlılık olduğunu kabul etmiştir (31). Bu nedenle hemşirelik öğrencilerinde duygusal zekânın yüksek olmasının hemşireliğin mesleki değerleri üzerine etkili olmasının önemli bir sonuç olduğu görülmektedir. 


\section{Kisıtlılıklar}

Araştırma tek bir kurumda gerçekleştirildiği için sonuçları tüm hemşirelik öğrencileri için geçerli değildir.

\section{Sonuçların Uygulamada Kullanımı}

Hemşirelik öğrencilerinin cinsiyetlerine göre duygusal zekâ düzeyleri arasında istatistiksel olarak anlamlı bir fark saptanmamıştır. Kız öğrencilerin erkeklere göre HMDÖ-R puanlarının daha yüksek olması mesleki değerlere uyumlarının daha güçlü olduğunu göstermiştir. Ancak erkek öğrencilerin hemşirelik değerlerinin duygusal zekâlarından kız öğrencilere göre daha yüksek düzeyde etkilendiği saptanmıştır. Kız öğrenciler erkek öğrencilere göre daha duygusal bulunmuştur. Hemşirelik öğrencilerinin cinsiyet farkı olmaksızın duygusal zekâ düzeyleri ile hemşirelik mesleği değerlerini algılarının doğru orantılı arttığı görülmüştür. Ayrıca hemşirelik öğrencilerinin cinsiyet farkı olmaksızın mesleklerini sevenlerin duygusal zekâ düzeylerinin yüksek olduğu ancak bu durumun hemşirelik mesleği değerlerini etkilemediği saptanmıştır. Bu durumun, hemşirelik öğrencilerinin duygusal zekâlarının mesleklerini severek yapmalarını sağlayacağını ve dolaylı olarak hasta bakım kalitesi ve memnuniyeti ile hemşirelerin mesleklerinden aldıkları doyumu artıracağı düşünülmektedir. Ayrıca duygusal zekâ düzeyi yüksek olan öğrencilerin empati yapma, liderlik, iletişim, stresle başetme, problem çözme, eleştirel düşünme, öz kontrol ve iyi oluşluk hallerinin yüksek olması beklenmektedir. Hemşirelik eğitiminde, öğrencilerin duygusal zekâlarını arttırıcı eğitim programları ve yöntemlerinin kullanılması önerilmektedir.

\section{Bilgilendirme}

Yazarların katkı oranı beyanı şu şekildedir: fikir ve kavram HO, HY; tasarım HY, HO; denetleme ve danışmanlık HO; veri toplama ve işleme HY; analiz ve yorum HY, EU, HO; kaynak taraması HY, EU, HO; makalenin yazımı HY, EU; eleştirel düşünme HY, HO. Araştırma ile ilgili herhangi bir projeden ya da firmadan destek alınmamıştır. Araştırmanın bütçesi araştırmacılar tarafından karşılanmıştır. Yazarlar arasında herhangi bir çıkar çatışması yoktur. Ayrıca sorumlu olduğumuz araştırmada herhangi bir firma ile çıkar ilişkisi bulunmamaktadır. Araştırmanın yapılabilmesi için bir üniversitenin Girişimsel Olmayan Araştırmalar Etik Kurulu'ndan 13.4.2017 Tarih 2017/08-17 karar numaralı etik kurul izni alınmıştır. 


\section{Kaynaklar}

1. Petrides KV, Fredericson N, Furnham A. The role of trait emotional Intelligance in academic performance and deviant behaviours at school. Pers Individ Dif 2004; 36(2): 277-293. doi: 10.1016/S0191-8869(03)00084-9

2. Petrides KV, Furnham A. Trait emotional intelligence: Psychometric investigation with reference to established trait taxonomies. Eur J Pers 2001;15(6): 425-448. doi:10.1002/per.416

3. Salavera C, Usan P, Jaire L. Emotional intelligence and social skills on self-efficacy in Secondary Education students. Are there gender differences? Journal of Adolescence 2017;60(1):39-46. doi:10.1016/j.adolescence.2017.07.009

4. Cerit B, Öz F. Hemşirelerin duygusal zekâ düzeyleri ile iletişim becerileri arasındaki ilişki. Sağlık Akademisi Kastamonu 2019;4(1):1-21. doi: 10.25279/sak.459199.

5. Köşgeroğlu N, Balcı Alparslan G, Babadağ B, Öztürk B, Ünver G. Hemşirelik öğrencilerinin duygusal zekâ düzeyleri ve problem çözme becerileri. JSHSR 2020;7(56):1969-1977.

6. Soylu P, Yılmaz M. Psikiyatri kliniğinde çalışan hemşirelerin duygusal zekâ düzeyleri ile stresle baş etme tarzları arasındaki ilişki. Sağlık ve Toplum 2017; 27(3):38-47.

7. Parsa Yekta Z, Mahbobeh A. Concept analysis of emotional intelligence in nursing. Nurs Pract Today 2015;2(4):158-163.

8. White DE, Grason S. The importance of emotional intelligence in nursing care. J Comp Nurs Res Care 2019;4:152. doi: 10.33790/jcnrc1100152

9. Çankaya M, Eriş H. Hemşire ve ebelerin duygusal zekâ düzeylerinin tespitine yönelik bir çalışma. ESoDer 2020;19(74):656664. doi:10.17755/esosder.567278

10. Acaroğlu R. Revize edilen hemşirelerin mesleki değerleri ölçeği Türkçe formunun güvenirlik ve geçerliği. FN Hem Derg 2014; 22(1):8-16.

11. Babadağ K. Hemşirelik ve Değerler. 1. Basım. Ankara Alter Yayıncılık; 2010.

12. Orak NŞ, Alpar ŞE. Hemşirelerin profesyonel değerleri ölçeğinin, geçerlik güvenirlik çalışması. Marmara Üniversitesi Sağlık Bilimleri Enstitüsü Dergisi 2012;2(1):22-31.

13. Göriş S, Kılıç Z, Ceyhan Ö, Şentürk A. Hemşirelerin profesyonel değerleri ve etkileyen faktörler. J Psychiatr Nurs 2014;5(3):137-142.

14. Sevindik F, Uncu F, Güneş Dağ D. Sağlık yüksekokulu öğrencilerinin duygusal zekâ düzeylerinin bazı değişkenler açısından incelenmesi. FÜ Sağ Bil Tıp Derg 2012; 26(1): 21-26.

15. Orak Niksarlı E. Hemşirelikte mesleki değerler ve duygusal zekâ ilişkisinin incelenmesi. TC. Haliç Üniversitesi Sağlık Bilimleri Enstitüsü Yüksek Lisans Tezi. İstanbul, 2017:97.

16. Çolak Okumuş D, Uğur E. Hemşirelerin duygusal zekâ düzeylerinin bakım davranışlarına etkisi. ACU Sağlık Bil Derg 2017;(2):104-109.

17. Sabancıoğlulları S, Doğan S. Profesyonel kimlik gelişimi ve hemşirelik. Anadolu Hemşirelik ve Sağlık Bilimleri Dergisi 2012;15(4):275-282.

18. Petrides K V, Furnham A. On the dimensional structure of emotional intelligence. Pers Individ Dif 2000;29:313-320.

19. Deniz ME, Özer E, Işık E. Duygusal zekâ özelliği ölçeği- kısa formu: geçerlik güvenirlik çalışması. Education and Science 2013;69(38):407-419.

20. Petrides KV. Technical Manual for the Trait Emotional Intelligence Questionnaires (TEIQue). 1. Edition. London Psychometric Laboratory; 2009: 2-24.

21. Petrides KV, Vernon PA, Schermer JA, Ligthart L, Boomsma DI, Veselka L. Relationships between trait emotional intelligence and the big five in the Netherlands. Pers Individ Dif 2010;48(8):906-910.

22. Weis D, Schank MJ. Development and psychometric evaluation of the nurses professional values scale-revised. J Nurs Meas 2009;17(3): 221-231.

23. Talmana K, Huplia M, Rankinb R, Engblomc J, Haavistoa E. Emotional intelligence of nursing applicants and factors related to it: A cross-sectional study. Nurse Education Today 2020;85(February):104271.doi:10.1016/j.nedt.2019.104271

24. Heydari A, Kareshki H, Reza Armat M. Is nurses' professional competence related to their personality and emotional intelligence? A cross-sectional study. J Caring Sci 2016;5(2): 121-132. doi: 10.15171/jcs.2016.013.

25. Karadağlı F. Hemşirelik öğrencilerinin profesyonel değer algıları ve etkileyen faktörler. Mersin Univ Saglık Bilim Derg 2016;9(2):81-91.

26. Carragher J, Gormley K. Leadership and emotional intelligence in nursing and midwifery education and practice: a discussion paper. J Adv Nurs 2017;73(1):85-96. doi: 10.1111/jan.13141.

27. Culha Y, Acaroğlu R. The relationship amongst student nurses' values, emotional intelligence and individualised care perceptions. Nurs Ethics 2019, Vol. 26(7-8) 2373-2383. doi: 10.1177/0969733018796682

28. Parandeh A, Khaghanizade M, Mohammadi E, Nouri JM. Factors influencing development of professional values among nursing students and instructors: A Systematic Review. Global J Health Sci 2015; 7(2): 284-93. doi:10.5539/gjhs.v7n2p284

29. Raghuir AE. Emotional intelligence in professional nursing practice: A concept review using Rodgers's evolutionary analysis approach. International Journal of Nursing Sciences 2018;⑵:126-130, doi: 10.1016/j.ijnss.2018.03.004

30. Altıok MY, Özer S, Nacar H, Yaman Z, Sungur MA. Klinisyen hemşirelerde duygusal zekâ: nitel ve nicel verilerle mersin örneği. Mersin Univ Saglık Bilim Derg 2015;8(2):48-59.

31. International Council of Nurses. The ICN Code of Ethics. Second Edition. ICN. Geneva. Switzerland; [online] 2012:1-10. URL: https://www.icn.ch/sites/default/files/inline-files/2012_ICN_Codeofethicsfornurses_\%20eng.pdf. 10 Haziran 2020 